\title{
RHEUMATISM IN DOCKERS AND CIVIL SERVANTS A COMPARISON OF HEAVY MANUAL AND SEDENTARY WORKERS
}

\author{
BY \\ R. E. H. PARTRIDGE AND J. J. R. DUTHIE \\ Arthritis and Rheumatism Council Industrial Survey Unit, Northern General Hospital, Edinburgh
}

The Industrial Survey Unit of the Arthritis and Rheumatism Council since 1961 has undertaken broad surveys of the prevalence and social and economic effects of rheumatic complaints among workers in several industries and occupations. Previous communications have given the results of surveys of men working in a coal mine (Anderson, Duthie, and Moody, 1962) and a naval dockyard (Anderson and Duthie, 1963), an electronic engineering factory (Partridge, Anderson, McCarthy, and Duthie, 1965), and a group of iron foundries (Partridge, Anderson, McCarthy, and Duthie, 1968).

To obtain information on as wide a range of occupations and working environments as possible, two further groups of men have been studied. They are (a) civil servants in a government department and (b) dockers in a civilian commercial dock. Men in these two occupations have been considered together for a number of reasons: the working environment of the two groups was in sharp contrast, there was a great difference in the physical effort demanded by the occupation, and both groups of men were essentially stable working populations with few transient workers, most of the men having been employed either as civil servant or as docker for most of their working lives.

\section{(1) Civil Servants}

\section{Background and Method}

Male civil servants from the rank of Clerical Officer through to Principal from the age of 15 to 65 were studied. The work was clerical, almost entirely sedentary, and performed in a warm pleasant environment. All men were salaried and during sickness absence received their normal pay for a variable number of weeks depending upon length of service.

\section{(2) Civilian Dockers}

The men concerned were occupied in loading and unloading a variety of raw materials and manufactured goods from merchant ships, and a few acted as drivers and checkers. Most of the work was done outdoors, although some time was spent in sheds. The casual labour system still operated and not all men worked every day. Although in theory all types of dockside job were open to any docker, in practice the men tended to form two main groups of heavy workers and light workers. A small number of men, mostly in the older age groups, were employed on a weekly wage basis and had physically less arduous tasks to perform. Sickness absence payment was from National Insurance only.

The nominal roles of all civil servants in four Government Departments and all dock workers in the port were obtained before the start of the survey. A random selection of men in each decade (15 to 64) was taken totalling approximately $\mathbf{4 0}$ per cent. of each nominal roll. No dockers under the age of 25 were employed in the port, so comparison has been made between men aged 25 to 64 only.

The men selected were asked to attend for interview and every effort was made to get as high an acceptance rate as possible, including home visiting of men off sick where this was practicable. At the time of interview a medical and social questionnaire was completed and a simple medical examination was made in the way described by Anderson and others (1962), except that all men were examined instead of only those complaining of rheumatism. The diagnoses on examination were made according to the criteria previously described (Anderson and others, 1962), but the complaints were grouped as follows:

(1) Lumbar disc disease.

(2) Pain in lumbar region, pelvic girdle, and legs of uncertain origin.

(3) Cervical disc disease.

(4) Pain in neck, shoulder girdle, and arms of uncertain origin.

Groups 1 and 2 and groups 3 and 4 were considered together for purposes of analysis.

(5) Osteoarthrosis, local and general.

(6) "Polyarthritis". Inflammatory polyarthritis of any type including rheumatoid arthritis. 
(7) Other specified rheumatic conditions (tenosynovitis, bursitis, capsulitis, etc.) not included in the above categories.

(8) Vague pain of uncertain origin.

Individual men were placed in more than one category if separate and distinct episodes of rheumatic pain had occurred separated by a number of years, or if more than one diagnosis was obvious to the observer at time of examination.

As in previous surveys, men complaining of rheumatism at the time of interview were designated "positives", those having symptoms at some other time "intermediates", and the rest, who denied symptoms, "negatives".

In addition to taking a general medical history and making a clinical examination, information was also obtained about sickness absence in the previous year with particular reference to duration and cause. A record was also made of change of occupation for reasons of ill health, use of medical services, and functional limitation.

\section{Statistical Tests}

Where applicable, the $\chi^{2}$ test has been used. Elsewhere, to make comparisons between age-standardized ratios, the test used was that applied to occupational mortality rates (Registrar General, 1951). Standardized ratios (SR), standardized complaint ratios (SCR), and standardized absence ratios (SAR) have been calculated from the fraction

\section{$\frac{\text { Observed Number }}{\text { Expected Number }} \times 100$}

The expected number was calculated by applying the complaint or absence rates for the specific age groups to the numbers in each occupation using the overall results as the standard (Anderson and Duthie, 1963).

\section{Results}

215 dock workers and 188 civil servants were asked to attend for interview; the completion rates were $206(95 \cdot 7$ per cent.) and 171 (91.0 per cent.) respectively.

The prevalence of rheumatic symptoms by age for both groups is shown in Table I. Although there were minor differences in prevalence in the different age groups, none of these reached a statistically significant level. In both occupations the expected rise in prevalence with increasing age was noted. For civil servants the expected number of positives was 56 (SCR 105.4); for dockers the expected number was 91 (SCR 97.8), a difference of no statistical significance. At all age groups a larger proportion of dockers were complaining of rheumatism at the time of interview, fifty (24.3 per cent.) compared with 25 (18.1 per cent.); the difference, however, was not significant $\left(\chi^{2}=1 \cdot 48 ; 0 \cdot 1<\mathrm{P}<0 \cdot 2\right)$.

\section{Diagnosis (Table II, opposite)}

A double diagnosis was made in seventeen civil servants $(12.3$ per cent.) and eighteen dockers ( 8.7 per cent.). The two civil servants with rheumatic symptoms in the 15 to 24 age group (omitted from the Table) had suffered from vague neck pain and Osgood-Schlatter's disease.

Low back pain (including lumbar disc disease), pelvic girdle pain, and leg pain occurred in 33 civil servants (SR 90.4) and 61 dockers (SR 106.1). The difference between the two groups was not significant $(2 \quad$ S.E. $=41 \cdot 6>15 \cdot 7 ; 0 \cdot 4<P<0 \cdot 5)$.

TABLE I

PREVALENCE QF RHEUMATIC COMPLAINTS

\begin{tabular}{|c|c|c|c|c|c|c|c|c|}
\hline \multirow{2}{*}{ Occupation } & \multirow{2}{*}{$\underset{\text { (yrs) }}{\text { Age }}$} & \multicolumn{2}{|c|}{ Positive } & \multicolumn{2}{|c|}{ Intermediate } & \multicolumn{2}{|c|}{ Negative } & \multirow{2}{*}{$\begin{array}{c}\text { Total } \\
\text { Interviewed } \\
\text { (100 per cent.) }\end{array}$} \\
\hline & & No. & Per cent. & No. & Per cent. & No. & Per cent. & \\
\hline \multirow{6}{*}{$\begin{array}{c}\text { Civil } \\
\text { Servants }\end{array}$} & $15-$ & 1 & $3 \cdot 0$ & 1 & $3 \cdot 0$ & 31 & $94 \cdot 0$ & 33 \\
\hline & $25-$ & 7 & $21 \cdot 9$ & 2 & $6 \cdot 3$ & 23 & $71 \cdot 8$ & 32 \\
\hline & $35-$ & 21 & $45 \cdot 7$ & 6 & $13 \cdot 0$ & 19 & $41 \cdot 3$ & 46 \\
\hline & $45-$ & 15 & $45 \cdot 5$ & 8 & $24 \cdot 2$ & 10 & $30 \cdot 3$ & 33 \\
\hline & $55-$ & 15 & $55 \cdot 6$ & 8 & $29 \cdot 6$ & 4 & $14 \cdot 8$ & 27 \\
\hline & All 15+ & 59 & $34 \cdot 5$ & 25 & $14 \cdot 6$ & 87 & 50.9 & 171 \\
\hline \multirow{6}{*}{ Dockers } & $15-$ & - & - & - & - & - & - & - \\
\hline & $25-$ & 8 & $30 \cdot 8$ & 3 & $11 \cdot 5$ & 15 & $52 \cdot 7$ & 26 \\
\hline & $35-$ & 25 & $38 \cdot 5$ & 16 & $24 \cdot 6$ & 24 & $36 \cdot 9$ & 65 \\
\hline & $45-$ & 21 & $42 \cdot 0$ & 9 & $18 \cdot 0$ & 20 & $40 \cdot 0$ & 50 \\
\hline & $55-$ & 35 & $53 \cdot 8$ & 12 & $18 \cdot 5$ & 18 & $27 \cdot 7$ & 65 \\
\hline & All 15+ & 89 & $43 \cdot 2$ & 40 & $19 \cdot 4$ & 77 & $37 \cdot 4$ & 206 \\
\hline
\end{tabular}


Back pain was complained of more by younger dockers particularly those under $35\left(\chi^{2}=3 \cdot 19\right.$; $0.05<P<0.1)$, and by civil servants over 55 $\left(x^{2}=1 \cdot 73 ; 0 \cdot 1<P<0 \cdot 2\right)$, but in neither group was the level of significance reached.

Pain referrable to the neck, shoulder girdle, and arm, including suspected cases of cervical disc disease, was noted with similar frequency below the age of 45 in both groups, but was a more common complaint in older civil servants than dockers of similar age. The overall difference between civil servants $(S R=134 \cdot 7)$ and dockers $(S R=76 \cdot 7)$ was below the level of significance $(2$ S.E. $=62 \cdot 2>58 \cdot 1$; $0.05<\mathrm{P}<0.1$ ), but if those over the age of 45 are considered the difference was significant $(P<0.05)$.

Among "positives" and "intermediates" osteoarthrosis was clinically apparent to the observer in thirteen civil servants $(9 \cdot 4$ per cent.; $S R=67 \cdot 0)$ and 44 dockers $(21 \cdot 3$ per cent.; $S R=117 \cdot 0)$. The difference between the two groups was on the borderline of significance $(2$ S.E. $=51>50 ; 0.05<P$ $<0 \cdot 1)$. Further analysis of men considered to have osteoarthrosis (Table III) showed that the major part of the difference was due to multiple joint involvement in 28 dockers (13.6 per cent.) compared with four civil servants (2.9 per cent.). A further 23 dockers (14 positives for another rheumatic condition and 9 negatives) and two civil service negatives had evidence of degenerative joint disease on examination, but admitted to no symptoms. One striking difference between the two groups was the common finding of joint deformities in the fingers, particularly the distal interphalangeal joints, of dock workers (36 men, $17 \cdot 5$ per cent.) and their comparative rarity in civil servants $(4 \mathrm{men}, 2.9$ per cent.). This difference could not be explained by the difference in age distribution of the two groups.

Of the 36 dockers with osteoarthrosis affecting the hands, distal interphalangeal joints of both hands were symmetrically involved in 22 of them (61 per

TABLE II]

DIAGNOSIS (Positives and Intermediates)

\begin{tabular}{|c|c|c|c|c|c|c|c|c|c|c|c|c|}
\hline \multirow{2}{*}{$\begin{array}{l}\text { Occupation } \\
\text { Age (yrs) }\end{array}$} & \multirow{2}{*}{$\cdots$} & \multirow{2}{*}{$\begin{array}{ll}\cdots & \cdots \\
\cdots & \cdots \\
\end{array}$} & \multicolumn{5}{|c|}{ Civil Servants } & \multicolumn{5}{|c|}{ Dockers } \\
\hline & & & $25-$ & $35-$ & $45-$ & $55-$ & All $25+$ & $25-$ & $35-$ & $45-$ & $55-$ & All $25+$ \\
\hline \multirow{8}{*}{ Diagnosis } & $\begin{array}{c}\text { Lumbar Disc } \\
\text { Disease }\end{array}$ & $\begin{array}{l}\text { No. } \\
\text { Per cent. }\end{array}$ & - & $\begin{array}{c}5 \\
10 \cdot 9\end{array}$ & $\begin{array}{l}2 \\
6 \cdot 1\end{array}$ & $\stackrel{8}{29 \cdot 6}$ & $\begin{array}{l}15 \\
10 \cdot 9\end{array}$ & $\stackrel{3}{11 \cdot 5}$ & $7 \cdot 7$ & $\stackrel{8}{16 \cdot 0}$ & $\begin{array}{c}7 \\
10 \cdot 8\end{array}$ & $\begin{array}{l}23 \\
11 \cdot 2\end{array}$ \\
\hline & $\begin{array}{l}\text { Back and Leg } \\
\text { Pain }\end{array}$ & $\begin{array}{l}\text { No. } \\
\text { Per cent. }\end{array}$ & $\begin{array}{l}3 \\
9 \cdot 4\end{array}$ & $\stackrel{8}{17 \cdot 4}$ & $\begin{array}{l}3 \\
9 \cdot 1\end{array}$ & $\stackrel{4}{14 \cdot 8}$ & $\begin{array}{l}18 \\
13 \cdot 0\end{array}$ & $\stackrel{5}{19 \cdot 2}$ & $\begin{array}{l}15 \\
23 \cdot 1\end{array}$ & $\begin{array}{l}7 \\
14 \cdot 0\end{array}$ & $\begin{array}{l}11 \\
15 \cdot 4\end{array}$ & $\begin{array}{l}38 \\
18 \cdot 4\end{array}$ \\
\hline & $\begin{array}{c}\text { Cervical Disc } \\
\text { Disease }\end{array}$ & $\begin{array}{l}\text { No. } \\
\text { Per cent. }\end{array}$ & - & $\begin{array}{l}2 \\
4 \cdot 3\end{array}$ & - & $\begin{array}{c}5 \\
18 \cdot 5\end{array}$ & $7 \cdot 5 \cdot 1$ & 二 & 2 & $2 \cdot 0$ & $1 \cdot 5$ & $\begin{array}{l}5 \\
2 \cdot 4\end{array}$ \\
\hline & $\begin{array}{l}\text { Neck and Shoulder } \\
\text { Girdle Pain }\end{array}$ & $\begin{array}{l}\text { No. } \\
\text { Per cent. }\end{array}$ & $\begin{array}{c}4 \\
12 \cdot 5\end{array}$ & $\begin{array}{c}6 \\
13 \cdot 0\end{array}$ & $21 \cdot 2$ & $2 \cdot 4$ & $\begin{array}{l}19 \\
13 \cdot 8\end{array}$ & $2 \cdot 7$ & 99 & $\stackrel{4}{8 \cdot 0}$ & 2 & $\begin{array}{c}17 \\
8 \cdot 3\end{array}$ \\
\hline & Osteoarthrosis & $\begin{array}{l}\text { No. } \\
\text { Per cent. }\end{array}$ & - & $\begin{array}{l}4 \\
8 \cdot 7\end{array}$ & $\begin{array}{l}3 \\
9 \cdot 1\end{array}$ & $22 \cdot 2$ & $\begin{array}{l}13 \\
9.4\end{array}$ & - & $\begin{array}{c}8 \\
12 \cdot 3\end{array}$ & $\begin{array}{c}9 \\
18 \cdot 0\end{array}$ & $27 \cdot 5$ & $24 \cdot 3$ \\
\hline & "Polyarthritis" & $\begin{array}{l}\text { No. } \\
\text { Per cent. }\end{array}$ & 2 & - & $\begin{array}{l}1 \\
3 \cdot 0\end{array}$ & $\stackrel{4}{14 \cdot 8}$ & $7 \cdot 1$ & - & 2 & $2 \cdot 0$ & $\begin{array}{l}4 \\
6 \cdot 2\end{array}$ & $\begin{array}{l}8 \\
3 \cdot 9\end{array}$ \\
\hline & $\begin{array}{l}\text { Other Specified } \\
\text { Rheumatic Conditions }\end{array}$ & $\begin{array}{l}\text { No. } \\
\text { Per cent. }\end{array}$ & 二 & $\frac{1}{2 \cdot 2}$ & $\begin{array}{l}3 \\
9 \cdot 1\end{array}$ & $\begin{array}{c}3 \\
11 \cdot 1\end{array}$ & $\begin{array}{l}7 \\
5 \cdot 1\end{array}$ & $\frac{1}{3} \cdot 8$ & - & $2 \cdot 0$ & $1 \cdot 5$ & $3 \cdot 5$ \\
\hline & $\begin{array}{l}\text { Vague Diffuse } \\
\text { Pain }\end{array}$ & $\begin{array}{l}\text { No. } \\
\text { Per cent. }\end{array}$ & 2 & $\stackrel{4}{8 \cdot 7}$ & $\stackrel{5}{15 \cdot 1}$ & $\frac{2}{7 \cdot 4}$ & $\begin{array}{l}13 \\
9 \cdot 4\end{array}$ & $\frac{1}{3 \cdot 8}$ & $\begin{array}{l}4 \\
6 \cdot 2\end{array}$ & $2 \cdot 0$ & $\frac{2}{3 \cdot 1}$ & $\begin{array}{l}9 \\
4 \cdot 4\end{array}$ \\
\hline \multicolumn{2}{|l|}{ No Symptoms } & $\begin{array}{l}\text { No. } \\
\text { Per cent. }\end{array}$ & $\begin{array}{l}23 \\
71 \cdot 8 \\
\end{array}$ & $\begin{array}{l}19 \\
41 \cdot 3 \\
\end{array}$ & $\begin{array}{l}10 \\
30 \cdot 3 \\
\end{array}$ & $\begin{array}{r}4 \\
14 \cdot 8 \\
\end{array}$ & $\begin{array}{l}56 \\
40 \cdot 6 \\
\end{array}$ & $\begin{array}{l}15 \\
52 \cdot 7 \\
\end{array}$ & $\begin{array}{l}24 \\
36 \cdot 9 \\
\end{array}$ & $\begin{array}{l}20 \\
40 \cdot 0 \\
\end{array}$ & $\begin{array}{l}18 \\
27 \cdot 7 \\
\end{array}$ & $\begin{array}{l}77 \\
37 \cdot 4 \\
\end{array}$ \\
\hline \multicolumn{3}{|c|}{ No. on which Percentage is Based } & 32 & 46 & 33 & 27 & 138 & 26 & 65 & 50 & 65 & 206 \\
\hline
\end{tabular}

TABLE III

DISTRIBUTION OF OSTEOARTHROSIS (1) Men Involved. (Precentages in brackets)

\begin{tabular}{|c|c|c|c|c|c|c|c|c|c|c|}
\hline \multirow[b]{2}{*}{ Occupation } & \multirow[b]{2}{*}{ Osteoarthrosis } & \multicolumn{6}{|c|}{ Single Joint } & \multicolumn{2}{|c|}{ Multiple } & \multirow[b]{2}{*}{ All Cases } \\
\hline & & Shoulder & Elbow & $\begin{array}{l}\text { Wrist/ } \\
\text { Hand }\end{array}$ & Hip & Knee & $\begin{array}{l}\text { Ankle/ } \\
\text { Foot }\end{array}$ & $\begin{array}{c}\text { Hands not } \\
\text { involved }\end{array}$ & $\begin{array}{l}\text { Hands } \\
\text { involved }\end{array}$ & \\
\hline $\begin{array}{c}\text { Civil } \\
\text { Servants }\end{array}$ & $\begin{array}{l}\text { Symptomatic } \\
\text { Symptomless }\end{array}$ & $3(2 \cdot 2)$ & 二 & $\begin{array}{l}1(0 \cdot 7) \\
2(1 \cdot 4)\end{array}$ & $1(0 \cdot 7)$ & $3(2 \cdot 2)$ & $1(0 \cdot 7)$ & $2(1 \cdot 4)$ & $2(1 \cdot 4)$ & $\begin{array}{rr}13 & (9 \cdot 4) \\
1 & (0 \cdot 7)\end{array}$ \\
\hline Dockers & $\begin{array}{l}\text { Symptomatic } \\
\text { Symptomless }\end{array}$ & $2(1 \cdot 0)$ & $\begin{array}{l}3(1 \cdot 5) \\
7(4 \cdot 4)\end{array}$ & $\begin{array}{r}1(0 \cdot 5) \\
14(6 \cdot 8)\end{array}$ & - & $7(3 \cdot 4)$ & $3(1 \cdot 5)$ & $9(4 \cdot 4)$ & $\begin{array}{r}19(9 \cdot 2) \\
2(1 \cdot 0)\end{array}$ & $\begin{array}{l}44(21 \cdot 3) \\
23(11 \cdot 2)\end{array}$ \\
\hline
\end{tabular}


cent.); both hands were irvolved asymmetrically in four. One hand only was involved in the remaining ten dockers (all in the asymptomatic group) and in seven of these a single distal inter phalangeal joint showed deformity from degenerative change. The pattern of joint involvement in men with osteoarthrosis is shown in Table IV. Every large joint in dockers was more often the site of symptomatic degenerative change; asymptomatic deformity occurred in ten dockers' elbows but in none of the civil servants examined. In dockers, the large joints of the right arm were involved nearly twice as often as those of the left (33 joints compared with 17).

Injury was of common occurrence among dockers; 45 out of $206(21 \cdot 8$ per cent.) had suffered episodes of trauma severe enough to cause fractures or dislocations since starting work (but not necessarily as a result of work) compared with ten out of 138 civil servants $(7 \cdot 2$ per cent.). The difference was significant $\left(x^{2}=12 \cdot 0 ; \mathrm{P}<0 \cdot 001\right)$. Osteoarthrosis of fifteen large joints in dockers was considered to have followed a definite episode of severe trauma, including all nine instances of osteoarthrosis of the ankle.

Other specified rheumatic conditions occurred 25 times (in 14 civil servants and 11 dockers). In this combined group there were four men with possible rheumatoid arthritis and eight men $(2 \cdot 3$ per cent.) with a previous history suggestive of an inflammatory polyarthritis that had remitted completely without residual joint damage. There were were also nine men with a history of tendinitis or capsulitis of a shoulder, elbow, or wrist, and single cases of shoulder-hand syndrome, osteo-chondritis dessicans, Behçet's syndrome, and gout. No cases of definite rheumatoid arthritis were seen in the sample.

\section{Effects on Working Capacity}

The functional capacity of every man was graded. The effects of rheumatic complaints on working capacity increased markedly with age. For dockers and civil servants combined, some functional limitation was apparent in nineteen out of 86 positives $(22 \cdot 1$ per cent.) over the age of 45 compared with five out of $61(8 \cdot 2$ per cent.) between the ages of 25 and 44.

When civil servants were compared with dockers, five out of 58 positive civil servants ( 8.6 per cent.) were noted to have some functional limitation and nineteen out of 89 dockers $(21.4$ per cent.) were also limited ( 2 S.E. $=76.6>68 \cdot 2 ; 0.05<P<0 \cdot 1)$. Five of these dockers were placed in the more severe grades of limitation but no civil servants showed more than a mild incapacity.

\section{Use of Medical Services}

The use of medical services is shown in Table $\mathrm{V}$ (positives and intermediates).

TABLE IV

DISTRIBUTION OF OSTEOARTHROSIS (2) Joints Involved (Percentages in brackets)

\begin{tabular}{|c|c|c|c|c|c|c|c|c|c|}
\hline Occupation & Osteoarthrosis & $\mathbf{R}_{\mathbf{L}}^{\text {Hand }}$ & $\mathbf{R}^{\text {Wrist }} \mathbf{L}$ & $\mathbf{R}^{\text {Elbow }} \mathbf{L}$ & $\begin{array}{l}\text { Shoulder } \\
\mathbf{R}\end{array}$ & $\mathbf{R}_{\mathbf{L}}^{\text {Hip }}$ & $\mathbf{R}^{\text {Knee }} \mathbf{L}$ & $\mathbf{R}^{\text {Ankle }} \mathbf{L}$ & $\begin{array}{l}\text { Total } \\
\text { Cases }\end{array}$ \\
\hline $\begin{array}{l}\text { Civil } \\
\text { Servants }\end{array}$ & $\begin{array}{l}\text { Symptomatic } \\
\text { Symptomless }\end{array}$ & $\begin{array}{ll}3 & 3 \\
(2 \cdot 2) & (2 \cdot 2) \\
(1 \cdot 4) & -\end{array}$ & $\begin{array}{ll}- & - \\
- & -\end{array}$ & $\begin{array}{ll}4 & 2 \\
(2 \cdot 9) & (1 \cdot 4) \\
- & -\end{array}$ & $\begin{array}{ll}3 & 4 \\
(2 \cdot 2) & (2 \cdot 9) \\
- & -\end{array}$ & $\begin{array}{ll}1 & - \\
(0 \cdot 7) & -\end{array}$ & $\begin{array}{c}5 \\
(3 \cdot 6) \\
-(3 \cdot 6) \\
-\end{array}$ & $\begin{array}{ll}1 & - \\
(0 \cdot 7) & -\end{array}$ & $\begin{array}{rr}13 & (9 \cdot 4) \\
2 & (1 \cdot 4)\end{array}$ \\
\hline Dockers & $\begin{array}{l}\text { Symptomatic } \\
\text { Symptomless }\end{array}$ & $\begin{array}{ll}20 & 20 \\
(9 \cdot 7) & (9 \cdot 7) \\
16 & 16 \\
(7 \cdot 8) & (7 \cdot 8)\end{array}$ & $\begin{array}{ll}5 & 1 \\
(2 \cdot 4) & (0 \cdot 5) \\
- & -\end{array}$ & $\begin{array}{cc}13 & 6 \\
(6 \cdot 3) & (2 \cdot 9) \\
6 & 4 \\
(2 \cdot 9) & (1 \cdot 9)\end{array}$ & $\begin{array}{ll}9 & 6 \\
(4 \cdot 4) & (2 \cdot 9) \\
- & -\end{array}$ & $\begin{array}{ll}4 & 2 \\
(1 \cdot 9) & (1 \cdot 0)\end{array}$ & $\begin{array}{ll}12 & 15 \\
(5 \cdot 8) & (7 \cdot 3) \\
- & -\end{array}$ & $\begin{array}{cc}4 & 5 \\
(1 \cdot 9) & (2 \cdot 4) \\
- & -\end{array}$ & $\begin{array}{l}4(21 \cdot 3) \\
23(11 \cdot 2)\end{array}$ \\
\hline
\end{tabular}

USE OF MEDICAL SER

\begin{tabular}{|c|c|c|c|c|c|c|c|c|}
\hline \multirow{3}{*}{ Medical Ser } & & \multirow{2}{*}{\multicolumn{2}{|c|}{$\begin{array}{l}\text { Hospital } \\
\text { Treatment } \\
\text { at Any Time }\end{array}$}} & $\begin{array}{l}\text { In- } \\
\text { patient }\end{array}$ & $1(11 \cdot 1)$ & - & $3(13 \cdot 0)$ & $4(17 \cdot 4) \mathrm{N}$ \\
\hline & ices & & & $\begin{array}{l}\text { Out- } \\
\text { patient }\end{array}$ & $1(11 \cdot 1)$ & $6(22 \cdot 2)$ & $5(21 \cdot 7)$ & $7(30 \cdot 4)$ \\
\hline & & \multicolumn{3}{|c|}{$\begin{array}{l}\text { Treatment by Family Doctor } \\
\text { in Past Year }\end{array}$} & $1(11 \cdot 1)$ & $3(11 \cdot 1)$ & $5(21 \cdot 7)$ & $6(26 \cdot 0) \stackrel{\mathbb{D}}{+}$ \\
\hline
\end{tabular}


Hospital treatment had been given to 26 out of 82 civil servants $(31 \cdot 8$ per cent.) and to 45 out of 129 dockers (34.9 per cent.). A similar proportion of these men, eight civil servants and ten dockers had been treated as in-patients. The commonest reasons for in-patient treatment were polyarthritis ( 7 cases) and disc disease (6 cases). Of the 53 men (18 civil servants and 35 dockers) referred to an outpatient department, the majority ( 28 men, 53.0 per cent.) were suffering from lumbar disc disease and low back pain. Cervical disc disease and shoulder girdle pain accounted for a further nine men (17.0 per cent.) and multiple joint pain of various types for eleven $(20 \cdot 8$ per cent.).

Medical treatment for rheumatic complaints from general practitioners in the year before interview had been obtained by fifteen civil servants ( $18 \cdot 3$ per cent.) and 41 dockers ( $31 \cdot 8$ per cent.). The difference between the two groups when standardized for age is just below the level of significance (2 S.E. $=51 \cdot 7>49 \cdot 7 ; 0.05<\mathrm{P}<0 \cdot 1$.

\section{Sickness Absence}

Sickness absence from rheumatic causes in civil servants in the year before interview was 31 weeks, or 22.5 weeks per 100 workers interviewed over the age of 25 , the loss being due to the absence of five out of 138 men (3.6 per cent.). Among dock workers sickness absence from rheumatism during the same period amounted to 110 weeks, or 53.4 weeks per 100 men interviewed, the loss of work being due to the absence of sixteen men ( 7.8 per cent.). The number of weeks lost from this cause and the rates per 100 men for each age group are shown in Table VI. 77 per cent. of rheumatic sickness absence in civil servants ( 24 weeks) was due to the absence of two men with specific inflammatory diseases, gout and Behçet's syndrome; only 5 weeks (16.1 per cent.) was lost from back pain. By contrast, the major cause of loss of work in dockers was lumbar disc disease and backache-together responsible for the loss of 75 weeks' work (68 per cent. of work lost). No civil servant was off work because of osteoarthrosis, but 16 weeks $(14.5$ per cent.) were lost from this cause among dockers.

The men were asked if they had lost time from work with rheumatic complaints at any time in the past, including the previous year; 65 dockers (31.5

TABLB VI

SICKNESS ABSENCE

\begin{tabular}{|c|c|c|c|c|c|c|c|c|c|c|c|c|}
\hline \multirow{2}{*}{$\frac{\text { Occupation }}{\text { Age (yrs) }}$} & \multirow{2}{*}{$\begin{array}{l}\ldots \\
\ldots\end{array}$} & \multirow{2}{*}{$\frac{}{\ldots}$} & \multicolumn{5}{|c|}{ Civil Servants } & \multicolumn{5}{|c|}{ Dockers } \\
\hline & & & $25-$ & $35-$ & $45-$ & $55-$ & All 25+ & $25-$ & $35-$ & $45-$ & $55-$ & All 25+ \\
\hline \multirow{6}{*}{$\begin{array}{l}\text { Cause of } \\
\text { Sickness } \\
\text { Absence }\end{array}$} & \multirow{2}{*}{ Rheumatism } & $\begin{array}{c}\text { Weeks off } \\
\text { in year }\end{array}$ & 0 & o & 21 & 10 & 31 & 15 & 24 & 28 & 43 & 110 \\
\hline & & $\begin{array}{l}\text { Rate per } \\
100 \text { men }\end{array}$ & 0.0 & 0.0 & $63 \cdot 6$ & $37 \cdot 0$ & $22 \cdot 5$ & $57 \cdot 7$ & $36 \cdot 9$ & $56 \cdot 0$ & $66 \cdot 2$ & 53.4 \\
\hline & \multirow{2}{*}{$\begin{array}{l}\text { Other } \\
\text { Causes }\end{array}$} & $\begin{array}{c}\text { Weeks off } \\
\text { in year }\end{array}$ & 17 & 49 & 41 & 29 & 136 & 18 & 86 & 78 & 266 & 448 \\
\hline & & $\begin{array}{l}\text { Rate per } \\
100 \text { men }\end{array}$ & $53 \cdot 1$ & $106 \cdot 5$ & $124 \cdot 2$ & $107 \cdot 4$ & $98 \cdot 5$ & $69 \cdot 2$ & $132 \cdot 3$ & $156 \cdot 0$ & $409 \cdot 2$ & $217 \cdot 5$ \\
\hline & \multirow{2}{*}{ All } & $\begin{array}{c}\text { Weeks off } \\
\text { in year }\end{array}$ & 17 & 49 & 62 & 39 & 167 & 33 & 110 & 106 & 309 & 558 \\
\hline & & $\begin{array}{l}\text { Rate per } \\
100 \text { men }\end{array}$ & $53 \cdot 1$ & $106 \cdot 5$ & $187 \cdot 8$ & $144 \cdot 4$ & $121 \cdot 0$ & $126 \cdot 9$ & $169 \cdot 2$ & $212 \cdot 0$ & $475 \cdot 4$ & 270.9 \\
\hline \multicolumn{3}{|c|}{ No. of Men Interviewed } & 32 & 46 & 33 & 27 & 138 & 26 & 65 & 50 & 65 & 206 \\
\hline
\end{tabular}

(Percentages in brackets)

\begin{tabular}{|c|c|c|c|c|c|}
\hline & \multicolumn{5}{|c|}{ Dockers } \\
\hline All $25+$ & $25-$ & $35-$ & $45-$ & $55-$ & All $25+$ \\
\hline $8(9 \cdot 8)$ & $1(9 \cdot 1)$ & $1(2 \cdot 4)$ & $3(10 \cdot 0)$ & $5(10.6)$ & $10(7 \cdot 8)$ \\
\hline $18(22 \cdot 0)$ & $5(45 \cdot 5)$ & $7(17 \cdot 1)$ & $9(30 \cdot 0)$ & $14(29 \cdot 8)$ & $35(27 \cdot 1)$ \\
\hline $15(18 \cdot 3)$ & $5(45 \cdot 5)$ & $13(31 \cdot 7)$ & $8(26 \cdot 6)$ & $15(31 \cdot 9)$ & $41(31 \cdot 8)$ \\
\hline 82 & 11 & 41 & 30 & 47 & 129 \\
\hline
\end{tabular}


per cent.) and 29 civil servants (21 per cent.) had done so $(2$ S.E. $=40>33.2 ; 0.05<P<0.1)$.

Sickness absence from non-rheumatic causes are also shown in Table VI. Civil servants lost 136 weeks in the year before interview $(98.5$ weeks per 100 workers), and 448 weeks were lost by dockers (217.5 weeks per 100 workers). The rate per 100 men for non-rheumatic sickness absence is higher in all decades among dockers and the difference is greatest in men over the age of 55 where the rate is more than three times that seen among civil servants of the same age group.

28 civil servants $(20 \cdot 3$ per cent.) and 63 dockers (30.6 per cent.) were off work from non-rheumatic causes during the year $\left(x^{2}=3.97 ; \mathrm{P}<0.05\right)$; the mean duration of absence for each man off sick was $4 \cdot 9$ weeks (civil servants) and $7 \cdot 1$ weeks (dockers). Thus the higher rate of sickness absence in dock workers was due to a larger number of men being off sick for a longer period of time. The frequency with which men were off sick for various nonrheumatic causes is shown in Table VII. More dockers than civil servants lost work from bronchitis, but the striking difference was seen in the number of men off work because of direct injury. This did not occur during the year in this group of civil servants, but 25 dockers $(12 \cdot 1$ per cent.) were off work for this reason.

The rate of non-rheumatic sickness absence for positives and for intermediates and negatives combined was calculated for each occupation. The observed rate of absence for positives among civil servants was 71 weeks per 100 men (expected rate 61 weeks); the observed rate for dockers was 203 weeks per 100 men (expected rate 215 weeks). In neither occupation, therefore, did rheumatic positives show a substantially different rate of absence from non-rheumatic causes.

\section{Change of Occupation}

Ten dockers (4.9 per cent.) had changed their occupation because of rheumatism and a further twenty $(9 \cdot 7$ per cent.) had done so for reasons of other ill-health. The majority of men had changed their occupation within the port authority, being downgraded to "Category C", which meant in effect employment on lighter work, or had transferred to a regular light job within the port at a weekly wage.

Three civil servants $(2 \cdot 2$ per cent.) had changed their job because of rheumatism, and seven $(5 \cdot 1$ per cent.) from other causes. All these men had entered the civil service after being disabled elsewhere.

\section{Discussion}

Previous studies from the Unit have shown clearly that the prevalence of rheumatic complaints increases with age, and the age structure of the population under study must be taken into account when comparing one occupation or industry with another. A comparison of the rheumatic complaint rate in dockers and civil servants with that in other industries is shown in Table VIII (opposite). Neither civil servants, with the 15 to 24 age group included (SCR 90.2; $0.3<P<0 \cdot 4$ ) nor dockers (SCR 94.4; $0.5<\mathrm{P}<0.6$ ) had complaint rates significantly different from what would be expected, taking the complaint rate by age for all men in all industries as the standard. This study confirms what has been noted in previous surveys, that a generally high level of rheumatic complaints exists throughout the community and that overall complaint rates do not vary significantly with the type of occupation or physical demands of the work involved, with certain notable exceptions such as coal miners (Anderson and others, 1962) and iron moulders (Partridge and others, 1968).

The two occupations represented here were completely dissimilar in the physical effort required and in the environmental working conditions, but similar numbers of men in each age group had been afflicted with some type of rheumatic complaint. There were, however, differences in the type of rheumatic complaint affecting men in the two occupations. Civil servants, in particular the older ones, complained of more pain in the neck and shoulder girdle than dockers. Much of the pain

TABLE VII

'REASONS FOR NON-RHEUMATIC SICKNESS ABSENCE

\begin{tabular}{|c|c|c|c|c|c|c|c|}
\hline Occupation & $\begin{array}{c}\text { Acute } \\
\text { Infections }\end{array}$ & Bronchitis & $\begin{array}{c}\text { Gastro- } \\
\text { Intestinal } \\
\text { Disease }\end{array}$ & Injury & $\begin{array}{l}\text { Other } \\
\text { Diseases }\end{array}$ & $\begin{array}{l}\text { Total No. } \\
\text { of Men } \\
\text { Sick }\end{array}$ & $\begin{array}{c}\text { Total No. of Men } \\
\text { Interviewed (on } \\
\text { which percentages } \\
\text { are based) }\end{array}$ \\
\hline $\begin{array}{l}\text { Civil Servants } \\
\text { Dockers }\end{array}$ & $\begin{array}{l}12(8 \cdot 7) \\
16(7 \cdot 8)\end{array}$ & $\begin{array}{r}3(2 \cdot 2) \\
10(7 \cdot 3)\end{array}$ & $\begin{array}{l}2(1 \cdot 5) \\
1(0 \cdot 7)\end{array}$ & $\begin{array}{c}0(0 \cdot 0) \\
25(12 \cdot 1)\end{array}$ & $\begin{array}{l}11(8 \cdot 0) \\
16(7 \cdot 8)\end{array}$ & $\begin{array}{l}28(20 \cdot 3) \\
63 *(30 \cdot 6)\end{array}$ & $\begin{array}{l}138 \\
206\end{array}$ \\
\hline
\end{tabular}

*Five dockers off work with two conditions. 
TABLB VIII

RHEUMATIC COMPLAINT RATE, BY INDUSTRY

\begin{tabular}{|c|c|c|c|c|c|c|c|c|c|c|}
\hline \multirow{2}{*}{\multicolumn{7}{|c|}{ Occupation }} & \multirow{3}{*}{$\frac{\begin{array}{c}\text { No. of } \\
\text { Workers } \\
\text { Interviewed }\end{array}}{402}$} & \multicolumn{2}{|c|}{ Number Positive } & \multirow{3}{*}{$\begin{array}{c}\begin{array}{c}\text { Standardized } \\
\text { Complaint } \\
\text { Ratio }\end{array} \\
117 \cdot 5\end{array}$} \\
\hline & & & & & & & & \multirow{2}{*}{$\begin{array}{c}\text { Observed } \\
185\end{array}$} & \multirow{2}{*}{$\frac{\text { Expected }}{157 \cdot 4}$} & \\
\hline Coal miners ... & $\cdots$ & $\cdots$ & $\ldots$ & . & $\cdots$ & $\ldots$ & & & & \\
\hline Brewery workers & . & $\cdots$ & $\cdots$ & . & . & $\cdots$ & 437 & 187 & $165 \cdot 2$ & $113 \cdot 2$ \\
\hline \multicolumn{3}{|c|}{ Electronic engineering workers } & . & . & $\ldots$ & . & 212 & 76 & $70 \cdot 5$ & $107 \cdot 8$ \\
\hline Foundry workers & $\ldots$ & . & . & $\ldots$ & $\ldots$ & $\cdots$ & 858 & 353 & $360 \cdot 3$ & $98 \cdot 0$ \\
\hline Civilian dockers & . & $\cdots$ & . & . & $\cdots$ & $\cdots$ & 206 & 89 & $94 \cdot 3$ & $94 \cdot 4$ \\
\hline \multicolumn{2}{|c|}{ Naval Dockyard workers } & $\ldots$ & . & $\cdots$ & $\cdots$ & $\cdots$ & 1,422 & 522 & $563 \cdot 7$ & $92 \cdot 7$ \\
\hline Civil servants .. & $\cdots$ & $\cdots$ & . & $\cdots$ & $\cdots$ & $\cdots$ & 171 & 59 & $65 \cdot 4$ & $90 \cdot 2$ \\
\hline Others ... & $\cdots$ & $\cdots$ & . & $\cdots$ & $\cdots$ & $\cdots$ & 110 & 48 & $41 \cdot 8$ & $114 \cdot 8$ \\
\hline Total $\ldots$ & $\cdots$ & $\cdots$ & $\cdots$ & . & $\cdots$ & $\cdots$ & 3,818 & 1,519 & $1,518 \cdot 6$ & 100 \\
\hline
\end{tabular}

in these men was comparatively minor and was responsible for little sickness absence. The pain was mostly aching in character and felt in the muscles and deep structures of the shoulder girdle; a classic history of radicular type of pain referred along a dermatone and suggestive of disc prolapse, was obtained in only a few men in either occupations. Although some of the shoulder girdle pain was probably due to cervical disc degeneration, an equally important factor may have been posture at work. Sedentary workers, who spend much of their working day leaning over a desk or table, without opportunity for exercise, may develop fatigue of the shoulder girdle muscles which may in turn throw a strain upon ligaments and apophyseal joints, particularly if the working surface is not at an optimum height for the individual worker.

In contrast to neck and shoulder girdle pain, the prevalence of back pain was similar in both groups of men, a proportion of whom were diagnosed as having lumbar disc disease. Kellgren and Lawrence (1952) have reported that, radiologically, dock workers show changes in the lumbar spine intermediate between the severe changes of coal miners and the milder changes of light manual workers and office workers. The present findings must be interpreted in the light of their report, but data from other studies carried out by the Industrial Survey Unit (Anderson, 1964; Partridge, 1968) suggest that only when stress on the back is severe (as in miners and moulders) does the complaint rate for back pain rise above the relatively high level of complaints in the general population. From light work through various grades of manual work (except the heaviest) the back complaint rate does not vary much.

The presence of physical signs in addition to symptoms strongly suggested the diagnosis of degenerative joint disease in 9.4 per cent. of civil servants and $21 \cdot 3$ per cent. of dockers, with a further $1 \cdot 4$ per cent. of civil servants and $11 \cdot 2$ per cent. of dockers also showing asymptomatic osteoarthrosis on examination. The difference, on the borderline of significance for the number of men involved, was mainly due to the presence of multiple joint osteoarthrosis and involvement of the hands in dockers, monoarticular disease being similar in the two groups. Distal interphalangeal joints were much more often involved than proximal interphalangeal or metacarpophalangeal joints, the appearances being similar to that of Heberden's nodes, although in all but one instance the changes were mild or moderate. Lawrence (1961) has commented on the increased prevalence of osteoarthrosis in the finger joints of cotton workers and noted that few gave a history of injury of these joints. A similar situation was noted in dockers and few men could remember any direct trauma to the hands. The finger joints, however, particularly the distal joints, may be subject to continual minor trauma at work which may go unheeded, or regarded as a normal occupational hazard. It is interesting that as in cotton workers, the hands were usually symmetrically involved as in primary generalized osteoarthrosis where a genetic factor is thought to operate. The single deformed distal joint, described by Stecher (1955) as being characteristic of traumatic Heberden's nodes, was seen in only a minority of cases. We have no information in this survey of the family background of the workers interviewed but it seems unlikely that a genetic factor could be operative here.

The suggestion that trauma may be a significant factor in producing finger changes is supported indirectly by the high incidence of major injuries recorded among dock workers (21.8 per cent.) compared with civil servants $(7 \cdot 2$ per cent.). Injuries of all kinds, both major and minor, were a 
notable cause of sickness absence in dockers. Undoubtedly the majority of their injuries occurred at work, and apart from the hazards of everyday living, dockers seem to be liable to injury from two causes: the men may fall from the deck into the ship's hold and more commonly heavy bales, logs, bags, or other objects may fall from a crane or the ship's side on to the men below. The degenerative changes noted in fifteen large joints could be directly attributed to an injury in the past, including all cases of osteoarthrosis of the ankle-joint, which is an uncommon site for this condition.

The role of heavy manual work itself in relation to the development of osteoarthrosis must also be considered. Partridge, Anderson, and Duthie (1964) showed that osteoarthrosis was more common among coal miners in the older age groups than among a comparative group of naval dockyard workers, and the condition was diagnosed more commonly in those miners who had worked at the coal face. It is commonly believed that there is a direct relationship between excessive use of a joint and the development of osteoarthrotic changes. This factor may obviously play a significant part in the osteoarthrosis of coal miners and dock workers, both of whom do hard physical work, but the additional factor of trauma, of common occurrence at the coal face and on the dockside, would seem to be equally important.

A comparison between rheumatic sickness absence rates in dockers, civil servants, and other workers in industry is shown in Table IX. The sickness absence ratio (SAR) was calculated in the way described by Anderson and Duthie (1963). Dockers (SAR 125.0), in common with other industrial workers, had a higher absence rate than expected, whereas the rate for civil servants (SAR 55.2) was much lower than expected, although not as low as that in electronic engineering workers (SAR 22.6). These results confirm the impression gained from previous surveys that there is a positive correlation between the heaviness of an occupation and the amount of sickness absence from rheumatic causes, even if the rheumatic complaint rate in different occupations does not vary a great deal. It is of interest that lumbar disc disease and backache, which has been shown to be the major factor responsible for rheumatic sickness absence among the working population (Partridge, 1968), was a minor cause of absence among civil servants in spite of the fact that the prevalence of back complaints was similar to that of dockers.

These findings may suggest that rheumatic complaints, although equally common in dock workers and civil servants, affect the heavy manual worker more severely. In keeping with this is the observation that functional limitation from rheumatism was greater among dock workers. The inability of the heavy manual worker to do his job when suffering from rheumatism as compared with the sedentary workers is reflected in the higher use of general practitioners' services by dock workers. Part of this is probably related to the need for sickness certificates, rather than the need for therapy, as the rate of referral to hospital for rheumatic complaints was similar in both groups. The rate of consultation of general practitioners by dockers was similar to that of other heavy industrial workers, but the rate for sedentary workers $(18.3$ per cent.) was similar to that of light manual workers (Partridge and others, 1965).

TABLE IX

RHEUMATIC SICKNESS ABSENCE RATE, BY INDUSTRY

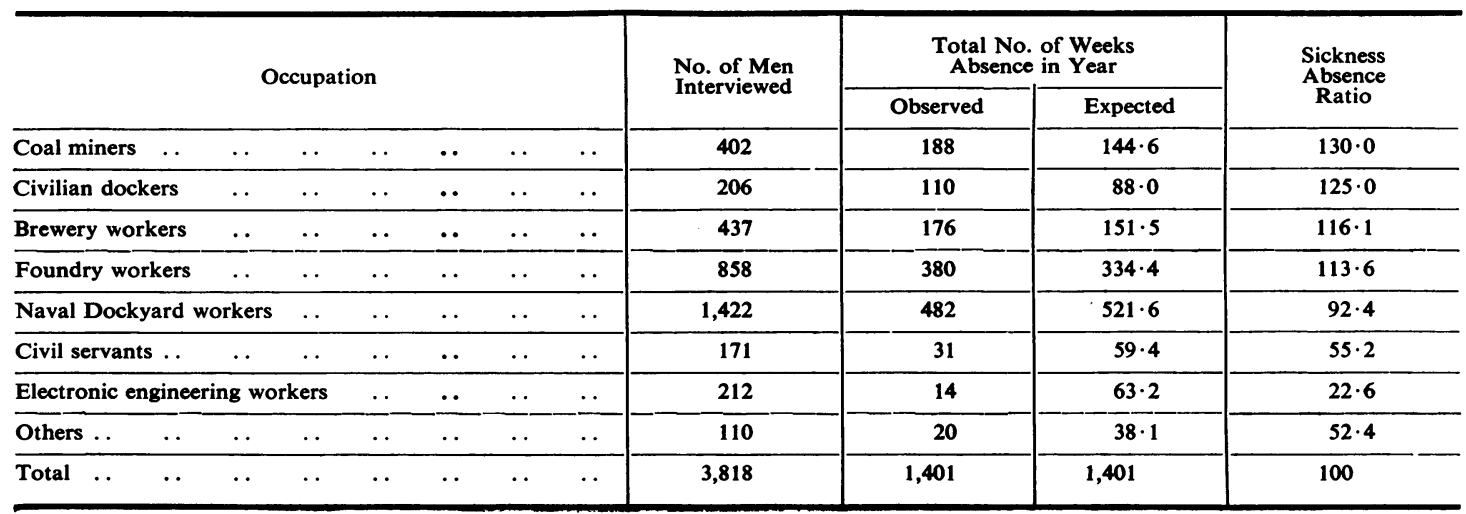




\section{Summary}

(1) A survey of 206 civilian dock workers (heavy manual workers) and 138 civil servants (sedentary workers) was carried out to assess the prevalence and social and economic effects of rheumatic complaints among them, and a comparison was made between the two groups.

(2) The annual complaint rate of the two groups was similar.

(3) The prevalence of osteoarthrosis was higher in dock workers and the prevalence of neck and shoulder girdle pain higher in civil servants.

(4) Injury was a common occurrence among dock workers and was thought to be an important factor in the development of osteoarthrosis in these men.

(5) Sickness absence from rheumatism in dockers was more than twice that in civil servants, and their use of general practitioners' services was also higher.

We wish to express our gratitude to the Arthritis and Rheumatism Council, who financed this project, and to Miss Rachel Spiers, Secretary to the Unit.

We are also grateful for the help and co-operation of the Departments of the Secretary of State for Scotland, the National Dock Labour Board, and members of the Transport and General Workers Union.

\section{- REFERENCES}

Anderson, J. A. D. (1964). " "Rheumatism in Industry". M.D. Thesis, University of Edinburgh.

— and Duthie, J. J. R. (1963). Ann. rheum. Dis., 22, 401 (Rheumatic complaints in dockyard workers).

—- - and Moody, B. P. (1962). Ibid., 21, 342 (Social and economic effects of rheumatic diseases in a mining population).

Kellgren, J. H., and Lawrence, J. S. (1952). Brit. J. industr. Med., 9, 197 (Rheumatism in miners. Part II. $X$-ray study).

Lawrence, J. S. (1961): Ibid., 18, 270 (Rheumatism in cotton operatives).

Partridge, R. E. H. (1968). “Annual Report of the Arthritis and Rheumatism Council for Research".

—, Anderson, J. A. D., and Duthie, J. J. R. (1964). Méd. et Hyg. (Genève), 22, 360 (Rheumatism in Industrial Workers).

—, - McCarthy, M.'A., and Duthie, J. J. R. (1965). Ann. rheum. Dis., 24, 332 (Rheumatism in Light Industry).

- _ _ _ _ - (1968). Ibid., 27, 441 (A survey of the prevalence and effects of rheumatic complaints among workers in iron foundries).

Registrar General (1958) "Decennial Supplement. England and Wales. Occupational Mortality, Part II, Volume I: Commentary". H.M.S.O., London.

Stecher, R. M. (1955). Ann. rheum. Dis., 14, 1 (Heberden's nodes, a clinical description of osteoarthrosis of the finger joints).

Le rhumatisme chez les dockers et les fonctionnaires

\section{RÉSUMÉ}

(1) On procéda à une enquête parmi 206 dockers (travail manuel lourd) et 138 fonctionnaires (travail sédentaire) pour évaluer la fréquence et les effets sociaux
El reumatismo en los estibadores y los funcionarios

\section{SUMARIo}

(1) Se investigaron 206 estibadores (trabajo manual duro) y 138 funcionarios (trabajo sedentario) respecto a la frecuencia y los efectos sociales y económicos de 
et économiques des manifestations rhumatoïdes parmi eux. On compara les deux groupes.

(2) La fréquence annuelle des manifestations était la même dans les deux groupes.

(3) La fréquence de l'ostéoarthrose était plus grande chez les dockers et la fréquence de la douleur dans le cou et dans la ceinture scapulaire était plus grande chez les fonctionnaires.

(4) Le traumatisme était fréquent chez les dockers et on pense qu'il prédisposait ces travailleurs à l'ostéoarthrose.

(5) L'absence pour maladie rhumatismale survenait deux fois plus souvent chez les dockers que chez les fonctionnaires et les dockers avaient aussi plus souvent recours aux services des médecins. manifestaciones reumatoides. Los dos grupos fueron comparados entre si.

(2) La frecuencia anual de manifestaciones fué similar en ambos grupos.

(3) Osteoartrosis fué más frecuente en los estibadores mientras que manifestaciones dolorosas en el cuello y en la cintura escapula lo fué en los funcionarios.

(4) El traumatismo ocurría a menudo en los estibadores y se cree que les predisponía a la osteoartrosis.

(5) Ausencias de trabajo atribuidas al reumatismo ocurrían con una frecuencia dos veces mayor entre los estibadores que entre los functionarios y los estibadores usaron más a menudo los servicios médicos. 